\title{
Laparoscopic Treatment of Splenic Injury in Blunt Abdominal Trauma
}

\author{
Ali I Yahya, Hussen E Shwerief, Rifat Latifi, Najala E Endaha, Fatma O Algyead
}

\begin{abstract}
Introduction: Road traffic accidents are very common and pose a serious community problem in Libya. In 1998, the surgery unit at Zliten Teaching Hospital began using laparoscopy in the trauma unit for patients who were admitted to intensive care unit. A challenge for trauma surgeons is negative laparotomy which can result in increased complications for patients.
\end{abstract}

Objective: We reviewed medical records following the implementation of laparoscopic techniques in the trauma unit to determine the effectiveness of the treatment with patients who had been in road traffic accidents.

Methods: Review of medical records for patients admitted to Zliten General Hospital in Libya who had been involved in road traffic accidents was conducted. The records analyzed were from 1998 through 2012.

Results: One hundred and twenty-four patients underwent diagnostic and therapeutic laparoscopy over the 14 years time period, of which 76 patients had blunt abdominal trauma. The review of Zliten's trauma registry shows that 18 patients had splenic trauma and those patients who had splenic trauma.

Out of the 18 patients who had blunt splenic trauma, three patients underwent laparoscopic splenectomy because it was not possible to preserve the spleen. One patient, aged 9 years, had an open laparotomy because the surgeons found that the spleen has avulsed completely and was lying at the left iliac fossa during diagnostic laparoscopy. Fourteen patients had small lacerations in the spleen. The spleen was not removed in these patients because profuse bleeding did not occur. No significant morbidity and no mortality were recorded. The hospital stay was between 2 and 5 days.

Conclusion: By using laparoscopy in trauma, we were able to preserve the spleen in the majority of our patients with splenic injuries who were hemodinamically stable.

Keywords: Laparoscopy, Trauma, Spleen.

How to cite this article: Yahya Al, Shwerief HE, Latifi R, Endaha NE, Algyead FO. Laparoscopic Treatment of Splenic Injury in Blunt Abdominal Trauma. J Trauma Critical Care Emerg Surg 2013;2(3):112-115.

\section{Source of support: Nil \\ Conflict of interest: None}

\section{RESUMEN}

Introducción: Los accidentes de tráfico son muy comunes y plantean un problema de la comunidad grave en Libia. En 1998, la unidad de cirugía en Zliten hospital docente comenzó a utilizar la laparoscopia en la unidad de trauma para los pacientes que ingresaron a la UIT. Un reto para los cirujanos de trauma es la laparotomía negativa que puede resultar en un aumento de complicaciones para los pacientes.
Objetivo: Se revisaron los registros médicos a raíz de la aplicación de las técnicas laparoscópicas en la unidad de trauma para determinar la eficacia del tratamiento con los pacientes que habían estado en los accidentes de tráfico.

Métodos: Se realizó revisión de las historias clínicas de los pacientes ingresados en el Hospital General de Zliten en Libia que habían estado involucrados en accidentes de tráfico. Los registros analizados fueron desde 1998 hasta 2012.

Resultados: 124 pacientes fueron sometidos a laparoscopia diagnóstica y terapéutica en el período de tiempo 14 años, de los cuales 76 pacientes tenían un traumatismo abdominal cerrado. La revisión de registro de trauma de Zliten muestra que 18 pacientes tenían traumatismo esplénico y aquellos pacientes que tenían eran sospecha de traumatismo esplénico tener una historia clínica, ya que estábamos usando los exámenes clínicos y las investigaciones.

Fuera de los dieciocho (18) de los pacientes que tenían traumatismo romo del bazo, tres pacientes fueron sometidos a esplenectomía laparoscópica porque no era posible preservar los bazos. Uno de los pacientes, con edades 9 años, tuvo una laparotomía abierta porque los cirujanos encontraron que el bazo ha avulsión completamente y yacía en la fosa ilíaca izquierda durante la laparoscopia diagnóstica. 14 pacientes tenían pequeños desgarros en el bazo. El bazo no fue eliminado en estos pacientes debido a sangrado profuso no ocurrió. No se registró una significativa morbilidad y mortalidad nula. La estancia hospitalaria fue de entre dos y cinco días.

Conclusiones: Mediante el uso de la laparoscopia en el trauma que éramos capaces de adoptar criterios de inclusión y exclusión para su uso, así como determinar la efectividad de este tipo de cirugía.

Palabras claves: La laparoscopia, El trauma, El bazo.

\section{INTRODUCTION}

Blunt abdominal trauma is a common form of injury and often occurs when an individual falls from a considerable height, when heavy objects fall on an individual, or from assault to the individual. Most commonly, however, blunt abdominal trauma is due to motor vehicle crashes. Abdominal trauma ranges from being trivial, where there is no internal bleeding to major, where there is solid organ injury, and moderate or severe trauma which consists of significant bleeding.

The laparotomy procedure can play a significant role in treating blunt abdominal trauma. In certain cases, wound severity is greater than in others. In cases of greater severity, scarring may occur as well as complications such as hernia or intestinal obstruction due to adhesions. These later complications may contribute to more hospital visits 
by the patient in situations of recurring attacks of intestinal adhesive obstruction.

While laparoscopy in trauma has been used for quite some time, laparoscopy has only recently been used for blunt trauma for purposes of diagnosing and treating these sorts of injuries. ${ }^{1-12}$

\section{METHODS}

The files of 76 patients who underwent laparoscopy for blunt abdominal trauma were reviewed for this study. Fifty-four of the 76 patients were male and 22 were female. Their ages ranged from 9 to 65 years. All of these patients were admitted to our ICU, had resuscitation according to ATLS protocols and full careful clinical examinations. Six patients who had GCS less than 8 were put on a ventilator. Other patients were conscious, but with different patterns of trauma and all patients had maintained vital signs. Upon abdominal examination, all of the patients had tender abdomens and looked moderately pale. All patients had routine investigations and $\mathrm{X}$-rays according to their specific injuries. A U/S scan of the abdomen was conducted for all patients as well. Ultrasounds showed fluid in the abdomen, mainly at the left upper quadrant and left iliac fossa. Three patients had clear splenic injuries. Although all patients had intravenous fluid and two units of blood prepared for each, none of them required blood transfusion before surgery.

All 76 patients with blunt abdominal trauma went for diagnostic laparoscopy under general anesthesia and four patients had the laparoscopy performed in ICU while they were on a ventilator, with closed pneumoperitoneum. The standard procedure is to start with $8 \mathrm{~mm} \mathrm{Hg}$ pressure and $11 \mathrm{~mm}$ port at umbilicus. Those patients whose trauma involved the spleen had three more ports added at the left side of the abdomen. All patients had prophylactic antibiotic third generation cephalosporin at the induction of anesthesia.

\section{RESULTS}

\section{Laparoscopic Findings}

Three patients had significant blood collection at the left side of the abdomen with splenic laceration grade 4 . In four patients, blood was suctioned and all abdominal organs were examined for injury. The position of the patient was changed to the lateral position, dissection of splenic pedicle and all small vessels were clipped with bioclamp. The splenic attachment to the colon and diaphragm were released as the spleen was removed through a $5 \mathrm{~cm}$ incision at the left upper quadrant with an ovum forceps and washed with saline and a big drain was left on the side of the spleen.

Six patients had small lacerations on the diaphragmatic surface of the spleen and were not bleeding significantly. For those patients who had small lacerations on the right lobe of the liver and were not bleeding significantly, a suction to collect blood and two drains was placed on each side. The drains were left for 24 hours and then removed.

For the eight patients who had only splenic lacerations which were not bleeding and had no other injuries, suction of the collected blood was performed and a drain was placed at the side of the spleen and left for 24 hours.

The 9-year-old boy who had no other injuries, upon laparoscopic examination, had the spleen avulsed at left iliac fossa, the procedure was converted to open, we removed the spleen and tied the splenic pedicle. A drain was placed in the left side of the abdomen for 48 hours.

Three patients had grade 4 splenic injury. Eight patients had simple laceration of the spleen alone. Six patients had simple splenic and liver trauma. One patient had an avulsed spleen. There was no operative mortality; however one patient required a blood transfusion during the splenectomy. There was no significant morbidity and the patient was

\begin{tabular}{|c|c|c|c|c|c|c|}
\hline $\begin{array}{l}P t \\
\text { no. }\end{array}$ & Age & Sex & $\begin{array}{c}\text { Mechanism of } \\
\text { trauma }\end{array}$ & Findings & Laparoscopic (action) & $\begin{array}{l}\text { Hospital } \\
\text { stay }\end{array}$ \\
\hline 1. & 17 & M & RTA & Lacerated spleen + fracture pelvis & Splenectomy & 5 days \\
\hline 2. & 35 & M & RTA & Long lacerated wound-spleen & Lap splenectomy & 5 days \\
\hline 3. & 40 & M & RTA & Multiple splenic wounds & Laparoscopic splenectomy & 5 days \\
\hline 4. & 25 & M & RTA & Small splenic wound & $\begin{array}{l}\text { Exploration hemoperitoneum, suction of } \\
\text { the blood/drain inserted }\end{array}$ & 3 days \\
\hline 5. & 30 & M & RTA & $\begin{array}{l}\text { Small tear at diaphragmatic surface of } \\
\text { spleen }\end{array}$ & $\begin{array}{l}\text { Hemoperitoneum/wound was not } \\
\text { bleeding hemostasis and insertion of } \\
\text { drain }\end{array}$ & 3 days \\
\hline 6. & 28 & M & RTA & $\begin{array}{l}\text { Two small splenic wounds } \\
\text { hemoperitoneum drain }\end{array}$ & $\begin{array}{l}\text { Suction of blood, small wounds not } \\
\text { bleeding }\end{array}$ & 4 days \\
\hline 7. & 38 & M & RTA & $\begin{array}{l}\text { Small splenic hematoma no expanding } \\
\text { little hemoperitoneum }\end{array}$ & Suction of blood, drain was inserted & 2 days \\
\hline 8. & 40 & M & RTA & Small splenic tear little hemoperitoneum & Suction of blood no other injury, drain & 3 days \\
\hline 9. & 38 & M & RTA & $\begin{array}{l}\text { Small splenic tear, not bleeding } \\
\text { significantly }\end{array}$ & Suction of blood drain inserted & 5 days \\
\hline
\end{tabular}

Contd... 
Laparoscopic Treatment of Splenic Injury in Blunt Abdominal Trauma

\begin{tabular}{|c|c|c|c|c|c|c|}
\hline \multicolumn{7}{|c|}{ Contd... } \\
\hline 10. & 25 & M & RTA & Tear in spleen, small liver tear & $\begin{array}{l}\text { Suction of hemoperitoneum no active } \\
\text { bleeding from splenic or liver tear }\end{array}$ & 3 days \\
\hline 11. & 30 & M & RTA & $\begin{array}{l}\text { Liver tears one wound on } \\
\text { diaphragmatic surface one on inferior } \\
\text { surface of liver small subcapsular } \\
\text { hematoma spleen }\end{array}$ & $\begin{array}{l}\text { Liver wounds sutured, hemoperitoneum } \\
\text { sucked splenic wound not bleeding }\end{array}$ & 3 days \\
\hline 12. & 32 & M & RTA & Stellate liver tear small splenic tear & $\begin{array}{l}\text { Liver wound sutured, splenic tear not } \\
\text { bleeding }\end{array}$ & 4 days \\
\hline 13. & 35 & M & RTA & $\begin{array}{l}\text { Small subcapsular splenic hematoma } \\
\text { liver tear at left lobe }\end{array}$ & $\begin{array}{l}\text { Liver tear sutured splenic wound not } \\
\text { bleeding }\end{array}$ & 3 days \\
\hline 14. & 25 & M & RTA & $\begin{array}{l}\text { Liver tear on* diaphragmatic surface. } \\
\text { *Splenic lacerated wound }\end{array}$ & $\begin{array}{l}\text { Liver tear sutured splenic not actively } \\
\text { bleeding }\end{array}$ & 5 days \\
\hline 15. & 40 & M & RTA & $\begin{array}{l}\text { Small tear or inferior surface of liver } \\
\text { long lacerated would on inferior pole } \\
\text { of spleen }\end{array}$ & $\begin{array}{l}\text { Suturing liver * tear surgical placed on } \\
\text { splenic tear }\end{array}$ & 3 days \\
\hline 16. & 38 & M & RTA & $\begin{array}{l}\text { Small splenic tear on diaphragmatic } \\
\text { surface }\end{array}$ & Splenic tear not bleeding & 3 days \\
\hline 17. & 52 & M & RTA & $\begin{array}{l}\text { Subcapsular splenic hematoma on } \\
\text { diaphragmatic surface }\end{array}$ & Hemostasis tears & 3 days \\
\hline 18. & 9 & M & RTA & $\begin{array}{l}\text { Hemoperitoneum spleen avulsed seen } \\
\text { at left iliac fossa }\end{array}$ & Converted to laparotomy & 8 days \\
\hline
\end{tabular}

discharged home. Those who had the splenectomy procedure were discharged on the 5 th postoperative day and those who had conservation of the spleen were discharged on the $3 \mathrm{rd}$ day (Table 1).

\section{DISCUSSION}

We conducted 124 laparoscopic procedures for blunt and penetrating abdominal trauma at the Zliten General Hospital in Libya between 1998 and 2012. The diagnostic laparoscopy has become a well-known procedure in trauma management since road traffic accidents are common problems in Libya. All hemodynamically unstable patients suspected of having splenic injury need laparotomy as soon as possible following admission. Patients who were stable but had intra-abdominal injury would not be safe if treated conservatively. Among these patients, a certain percentage could have ended in negative laparotomy. With the use of diagnostic and therapeutic laparoscopy, certain patients were saved from having negative laparotomy and these patients benefited from having therapeutic laparoscopy. ${ }^{13-25}$ Based upon our experiences with these laparoscopic procedures, we agreed to adopt some inclusion and exclusion criteria for the use of laparoscopy in trauma.

\section{Inclusion Criteria}

1. The patient should be hemodynamically stable.

2. The clinical examination should reveal positive abdominal findings indicating intra-abdominal injury.

3. The ultrasound should show intra-abdominal collection or solid organ injury.

\section{Exclusion Criteria}

1. The patient is in unstable condition.

2. The patient's condition is deteriorating rapidly.

3. An experienced surgeon in laparoscopy is not available. For this study, we performed diagnostic and therapeutic laparoscopy for patients suspected of having splenic trauma with or without other intra-abdominal trauma; however, we performed three laparoscopic splenectomies because we found that they had large splenic lacerations and it was not possible to save the spleen. With excellent laparoscopic equipment and new versions of hemostatic machines such as the bioclamp, a splenectomy can be done safely since the minor lacerations of the spleen can be evaluated and seen better with laparoscopy as well as other visceral injuries can be diagnosed through laparoscopic examination. The outcome is that the metabolic changes resulting from traumatic surgery are less, there are no large wounds, less hernias and wound infections as well as earlier discharge from the hospital. Finally, there are no significant adhesions to be dealt with in the future. Before the use of laparoscopy, there was a higher likelihood that the patient might have ended in a negative laparotomy especially if he was admitted during hours (i.e. late in the evening) when access to ultrasound scan and CT scan were limited. Hence, with the use of laparoscopy we could save patients from negative laparotomy and their spleen would be left untouched when they have minor injuries. If spleen removal were needed, it could be done safely and effectively using key-hole surgery techniques. 


\section{CONCLUSION}

Use of laparoscopy in blunt splenic trauma is a safe procedure in hemodynamically stable patients. With the use of laparoscopy, the patient will be saved from the complications of a large wound, and a long hospital stay. Additionally, intra-abdominal viscera are inspected more accurately. Finally, the use of laparoscopy in blunt splenic trauma can also avoid negative laparotomy, which poses a significant challenge for trauma surgeons

\section{REFERENCES}

1. Huscher CG, Mingoli A, Sgarzini G, Brachini G, Ponzano C, Di Paola M, Modini C. Laparoscopic treatment of blunt splenic injuries: initial experience with 11 patients. Surg Endo 2006 Sept;20(9)1423-1426.

2. Carobbi A, Romagnani F, Antonelli G, Bianchini M. Laparoscopic splenectomy for severe blunt trauma: initial experience of ten consecutive cases with a fast hemostatic technique. Surg Endosc 2010 Jun;24(6):1325-1330.

3. Sotomayor-Ramírez RK, Efficacy and safety of laparoscopic splenectomy: review of 14 adult cases using the lateral approach. Bol Asoc Med PR 2009 Apr-Jun;101(2):43-49.

4. Ayiomamitis GD, Alkari B, Owera A, Ammori BJ. Emergency laparoscopic splenectomy for splenic trauma in a Jehovah's Witness patient. Surg Laparosc Endosc Percutan Tech 2008 Dec;18(6):626-630.

5. Ransom KJ, Kavic MS. Laparoscopic splenectomy for blunt trauma: a safe operation following embolization. Surg Endosc. $2009 \mathrm{Feb} ; 23(2): 352-355$.

6. Latic F, Delibegovic S, Latic A, Miskic D, Pitlovic V, Koluh A. Laparoscopic splenectomy in blunt trauma: is the procedure safe in pregnant patient? Med Arh 2010;64(1):51-52.

7. Pietra N, Carreras F, Longinotti E, Violi V, Sarli L. Videolaparoscopy and conservative treatment of splenic injuries. Acta Biomed Ateneo Parmense 1992;63(3-4):317-321.

8. Agarwal N. Laparoscopic splenectomy in a case of blunt abdominal trauma. J Minim Access Surg 2009 Jul-Sep;5(3):78-81.

9. Nasr WI, Collins CL, Kelly JJ. Feasibility of laparoscopic splenectomy in stable blunt trauma: a case series. J Trauma 2004 Oct;57(4):887-889.

10. De Wilt JH, Van Eijck CH, Hussain SM, Bonjer HJ. Laparoscopic spleen preserving distal pancreatectomy after blunt abdominal trauma. Injury 2003 Mar;34(3):233-234.

11. Basso N, Silecchia G, Raparelli L, Pizzuto G, Picconi T. Laparoscopic splenectomy for ruptured spleen: lessons learned from a case. J Laparoendoscopic Adv Surg Tech A 2003;13: 109-112.

12. Kwon AH, Inui H, Kamiyama Y. Successful laparoscopic hemostasis using an argon beam coagulator for blunt traumatic splenic injury. Eur J Surg 2001 Apr;167(4):316-318.

13. Collin GR, Bianchi JD. Laparoscopic examination of the traumatized spleen with blood salvage for autotransfusion.m Surg 1997 Jun;63(6):478-480.

14. Bové T, Delvaux G, Van Eijkelenburg P, De Backer A, Willems G. Laparoscopic-assisted surgery of the spleen: clinical experience in expanding indications. J Laparoendosc Surg 1996 Aug;6(4):213-217.
15. Targarona EM, Trías M. Laparoscopic treatment of splenic injuries. Semin Laparosc Surg 1996 Mar;3(1):44-49.

16. Rizk N, Champault G, Boutelier P. Laparoscopic splenic salvage in blunt abdominal trauma. Acta Chir Belg 1995; 95(4 Suppl):202.

17. Koehler RH, Smith RS, Fry WR. Successful laparoscopic splenorrhaphy using absorbable mesh for grade III splenic injury: report of a case. Surg Laparosc Endosc 1994 Aug;4(4):311-315.

18. Smith RS, Meister RK, Tsoi EK, Bohman HR. Laparoscopically guided blood salvage and autotransfusion in splenic trauma: a case report. J Trauma 1993 Feb;34(2):313-314.

19. Pietra N, Carreras F, Longinotti E, Violi V, Sarli L. Videolaparoscopy and conservative treatment of splenic injuries. Acta Biomed Ateneo Parmense 1992;63(3-4):317-321.

20. Latic F, Delibegovic S, Latic A, Miskic D, Pitlovic V, Koluh A. Laparoscopic splenectomy in blunt trauma: is the procedure safe in pregnant patient? Med Arh 2010;64(1):51-52.

21. Carobbi A, Romagnani F, Antonelli G, Bianchini M. Laparoscopic splenectomy in a case of blunt abdominal trauma. J Minim Access Surg 2009 Jul-Sep;5(3):78-81.

22. Carobbi A, Romagnani F, Antonelli B, Bianchini M. Laparoscopic splenectomy for severe blunt trauma: initial experience of ten consecutive cases with a fast hemostatic technique. Surg Endosc 2010 Jun;24(6):1325-1330.

23. Svébis M, Pap-Szekeres J, Venczel L, Gera L, Rajtár M, Sinkó M, Furka I, Mikó I. Early clinical experience with postoperative monitoring of a patient after laparoscopic splenectomy combined with spleen autotransplantation. A case report. Magy Seb 2005 Apr;58(2):80-83.

24. Schmai H, Geiger G. Laparoscopic splenic salvage in delayed rupture by application of fibrin glue in a 10 -year-old boy. J Trauma 2005 Mar;58(3):628-630.

25. Schnüriger B, Lam L, Inaba K, Kobayashi L, Barbarino R, Demetriades D. Negative laparotomy in trauma: are we getting better? Am Surg 2012 Nov; 78(11):1219-1223.

\section{ABOUT THE AUTHORS}

\section{Ali I Yahya}

Department of General Surgery, Zliten University Hospital, Zliten Libya

\section{Hussen E Shwerief}

Department of General Surgery, Zliten University Hospital, Zliten Libya

\section{Rifat Latifi (Corresponding Author)}

Department of General Surgery, University of Arizona, Tucson Arizona, USA, e-mail: rlatifi@email.arizona.edu

\section{Najala E Endaha}

Department of General Surgery, Zliten University Hospital, Zliten Libya

\section{Fatma O Algyead}

Department of General Surgery, Zliten University Hospital, Zliten Libya 